University of Nebraska - Lincoln

DigitalCommons@University of Nebraska - Lincoln

2000

\title{
Occurrence of pesticides in rain and air in urban and agricultural areas of Mississippi, April-September 1995
}

R. H. Coupe

U.S. Geological Survey, rhcphd@gmail.gov

M. A. Manning

U.S. Geological Survey

W. T. Foreman

U.S. Geological Survey

D. A. Goolsby

U.S. Geological Survey

M. S. Majewski

U.S. Geological Survey

Follow this and additional works at: https://digitalcommons.unl.edu/usgsstaffpub

Part of the Earth Sciences Commons

Coupe, R. H.; Manning, M. A.; Foreman, W. T.; Goolsby, D. A.; and Majewski, M. S., "Occurrence of pesticides in rain and air in urban and agricultural areas of Mississippi, April-September 1995" (2000). USGS Staff -- Published Research. 368.

https://digitalcommons.unl.edu/usgsstaffpub/368

This Article is brought to you for free and open access by the US Geological Survey at DigitalCommons@University of Nebraska - Lincoln. It has been accepted for inclusion in USGS Staff -- Published Research by an authorized administrator of DigitalCommons@University of Nebraska - Lincoln. 


\title{
Occurrence of pesticides in rain and air in urban and agricultural areas of Mississippi, April-September 1995
}

\author{
R.H. Coupe ${ }^{\mathrm{a}, *}$, M.A. Manning ${ }^{\mathrm{a}}$, W.T. Foreman ${ }^{\mathrm{b}}$, D.A. Goolsby ${ }^{\mathrm{c}}$, \\ M.S. Majewski ${ }^{\mathrm{d}}$ \\ ${ }^{a}$ US Geological Survey, 308 South Airport road, Pearl, MS 39208-6649, USA \\ ${ }^{\mathrm{b}}$ US Geological Survey, MS-407, Box 25046, Denver, CO 80225-0046, USA \\ ${ }^{\mathrm{c}}$ US Geological Survey, MS-406, Box 25046, Denver, CO 80225-0046, USA \\ ${ }^{\mathrm{d}}$ US Geological Survey, Placer Hall, 6000 J Street, Sacramento, CA 95819-6129, USA
}

\begin{abstract}
In April 1995, the US Geological Survey began a study to determine the occurrence and temporal distribution of 49 pesticides and pesticide metabolites in air and rain samples from an urban and an agricultural sampling site in Mississippi. The study was a joint effort between the National Water-Quality Assessment and the Toxic Substances Programs and was part of a larger study examining the occurrence and temporal distribution of pesticides in air and rain in the Mississippi River basin. Concurrent high-volume air and wet-only deposition samples were collected weekly. The air samplers consisted of a glass-fiber filter to collect particles and tandem polyurethane foam plugs to collect gas-phase pesticides. Every rain and air sample collected from the urban and agricultural sites had detectable levels of multiple pesticides. The magnitude of the total concentration was 5-10 times higher at the agricultural site as compared to the urban site. The pesticide with the highest concentration in rain at both sites was methyl parathion. The pesticide with the highest concentration in the air samples from the agricultural site was also methyl parathion, but from the urban site the highest concentration was diazinon followed closely by chlorpyrifos. More than two decades since $p, p^{\prime}$-DDT was banned from use in the United States, $p, p^{\prime}$-DDE, a metabolite of $p, p^{\prime}$-DDT, was detected in every air sample collected from the agricultural site and in more than half of the air samples from the urban site. (c) 2000 Elsevier Science B.V. All rights reserved.
\end{abstract}

Keywords: Pesticides; Insecticides; Herbicides; Air; Rain; Mississippi; Methyl Parathion; DDE; Chlorpyrifos

\footnotetext{
* Corresponding author. Tel.: +1-601-933-2982; fax: +1-601-933-2901.

E-mail address: rhcoupe@usgs.gov (R.H. Coupe)
} 


\section{Introduction}

Pesticides are widely used in the United States to protect crops from pests, to reduce crop yield loss, and to increase the comfort and safety of citizens. Although the use of pesticides has resulted in increased crop production and other benefits, there is concern about the ultimate fate of pesticides. Pesticides have the potential to contaminate the hydrologic cycle when they move from their point of application. One potential path for off-site movement is through the atmosphere. Small amounts of pesticides can be transported long distances through the atmosphere and deposited into aquatic and terrestrial ecosystems far from their point of use (Majewski and Capel, 1995). Atmospheric transport can occur in the gas phase through volatilization or in the particulate phase when attached to dust particles, or a combination of both depending on the pesticide's physical and chemical properties. After introduction into the atmosphere, pesticides can be degraded, transported, and redeposited. Deposition can be either wet such as with rain or snow or dry such as gaseous sorption and particle fallout.

There have been several studies that have examined the movement of pesticides in the atmosphere, and an excellent review of many of the major studies is in Majewski and Capel (1995). In Mississippi, there have been a limited number of studies on the transport of pesticides in the atmosphere. Many of these studies have dealt with the volatilization of pesticides after application (Hollingsworth, 1980; Willis et al., 1980, 1983; Harper et al., 1983). Hollingsworth (1980), examined volatilization of trifluralin after incorporation, the other studies examined toxaphene or DDT or both. Arthur et al. (1976) collected weekly air samples and analyzed them for a suite of pesticides, most of which have since been discontinued in the United States. There have been a few national studies that have included agricultural and urban sites in Mississippi, (Tabor, 1965; Stanley et al., 1971; Kutz et al., 1976), but these studies focused on pesticides that were then in use, most of which are no longer used in the United States.
In June 1994, Majewski et al. (1998) collected air samples during a cruise up the Mississippi River from New Orleans, Louisiana to St. Paul, Minnesota. This was a precursor to the current study and used the same equipment and analytical techniques. Their results indicated that the occurrence and atmospheric concentration of the observed pesticides were most closely related to their use within $40 \mathrm{~km}$ of the river. Additionally, some pesticides heavily used in urban areas such as chlorpyrifos, diazinon, and malathion had their highest concentration near urban areas. There have been no other studies on pesticides in the atmosphere in Mississippi in recent years. The purpose of this paper is to present the results of a study of pesticides in rain and air, collected from an urban and an agricultural setting in Mississippi by the US Geological Survey (USGS) from April 12 to September 19, 1995. The results reported here are a part of a larger study of pesticides in the atmosphere in the Mississippi River valley (Majewski et al., this volume, and Foreman et al., this volume).

\section{Materials and methods}

\subsection{Sampling sites}

The urban sampling site is located in Hinds County, Mississippi, in a residential neighborhood of the south Jackson metropolitan area (Fig. 1). The site was chosen to represent urban air and is several kilometers from the nearest agricultural field.

The agricultural sampling site is in the center of a catfish pond complex near the town of Rolling Fork in Sharkey County, Mississippi (Fig. 1). This area is in the Mississippi River alluvial plain and is one of the most intensively farmed areas in the United States. The major crops were soybean, cotton, corn, and rice. The site location was selected to minimize the influence of direct application of pesticides to nearby fields. The nearest agricultural field was approximately $1 \mathrm{~km}$ away.

\subsection{Sampling procedures}

Weekly samples of wet-only deposition were 


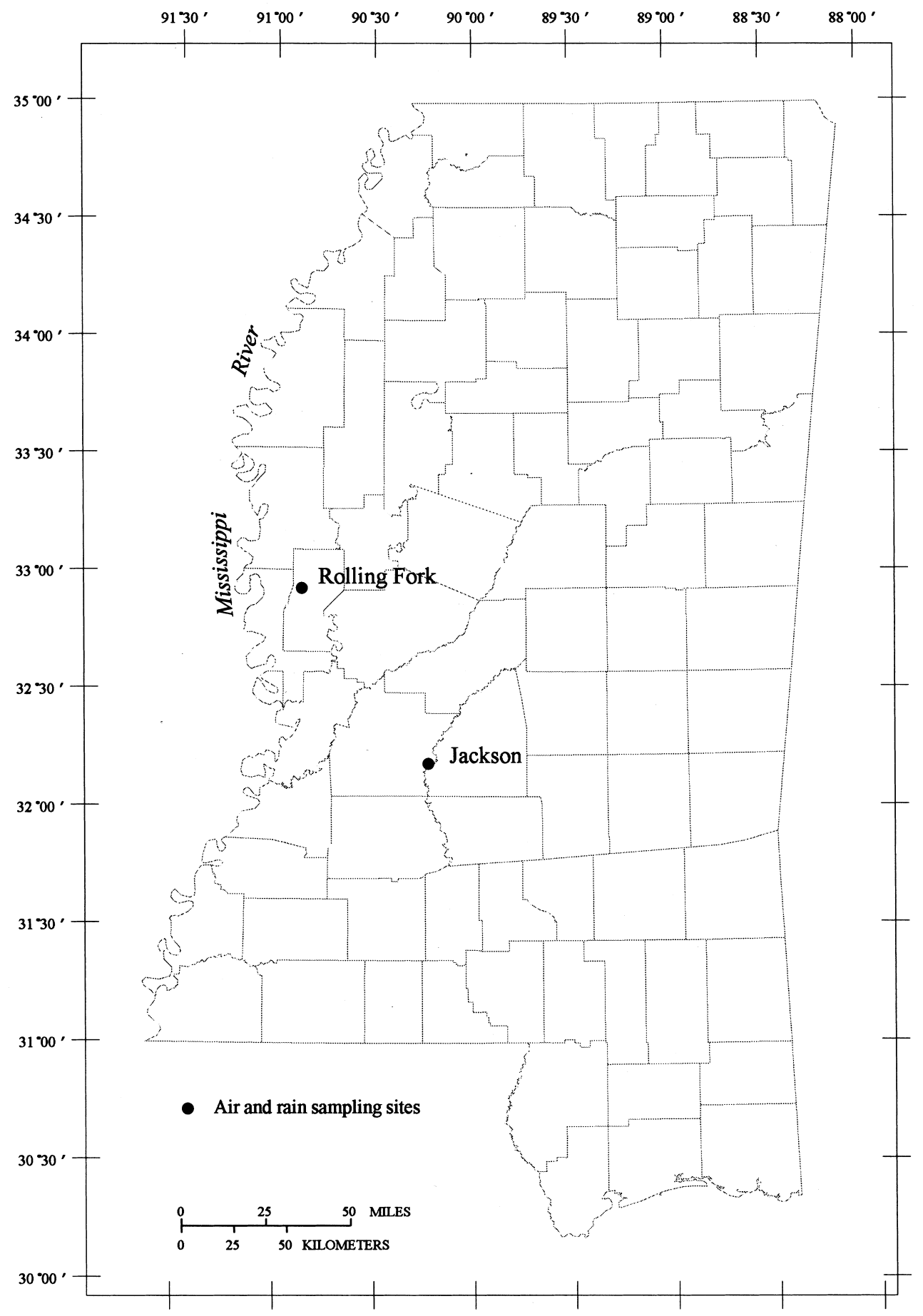

Fig. 1. Location of air and rain sampling sites, April-September 1997. 
collected by using a modified Aerochem Metric Precipitation Collector (any use of trade, product, or firm names is for descriptive purposes only and does not imply endorsement by the US Government). This collector is equipped with a moisture sensor that triggers the lid of the collection bucket to open when rain begins and to close when the rain ends. The collector was modified by installing a Teflon-coated funnel in the collection bucket and attaching a Teflon tube from the funnel through the bottom of the bucket into the top of a small refrigerator and into a glass bottle. The inside of the refrigerator was maintained at $4^{\circ} \mathrm{C}$.

Rain samples were collected weekly, if there had been enough precipitation. Samples were transported to the USGS office, and a 1-1 aliquot was withdrawn and passed through a C-18 solidphase extraction cartridge for isolation of the compounds of interest. The cartridge was then sent to the National Water Quality Laboratory (NWQL) in Arvada, CO, USA. Samples were eluted from the cartridges with solvent and analyzed for 47 pesticides and pesticide degradates by gas chromatography/mass spectrometry (GC/MS) using selected ion monitoring (SIM) (Zaugg et al., 1995).

The last rain sample from the urban site was collected during the week of August 15-22 and the last rain sample for the agricultural site was collected the week of August 29-September 5. During the week of April 19-26, more than $20 \mathrm{~cm}$ of rain fell at both sites. The sample bottles were designed to hold approximately $13 \mathrm{~cm}$ of rain. At the agricultural site, the sample bottle was replaced on April 22; however, the urban site could not be accessed, and the sample bottle overflowed. In all, there was sufficient rainfall for 16 weekly samples from the urban site and 15 weekly samples and one midweek sample at the agricultural site out of a possible 24 weekly samples.

The air sampling train consisted of a baked glass-fiber filter $(\mathrm{GFF}), 21.6 \times 27.9 \mathrm{~cm}$, to collect particles and tandem polyurethane foam (PUF) plugs, of $8.9 \times 7.6 \mathrm{~cm}$ diameter, to collect gasphase pesticides. The air was pulled through the GFF and then through the PUFs at approximately $1 \mathrm{~m}^{3} / \mathrm{min}$ using a high volume sampler
(Graesby-Anderson Inc.). The PUFs were mounted in tandem and analyzed separately to estimate the efficiency of the two PUFs for the collection of gas-phase pesticides. If a pesticide was detected on the first PUF and not on the second, it was assumed that the gas-phase pesticide was completely collected by the first PUF. If, however, there was an equal or larger amount of the pesticide on the second PUF, as on the first, then it was assumed that extraction of the pesticide by the PUFs was not complete and the concentrations derived from the PUFs must be considered a minimum. Diazinon, molinate, and trifluralin had concentrations on the second PUF equal to or more than on the first PUF. These concentrations are considered minimums; the actual concentrations were higher.

At the beginning of the study (April 12, 1995) the air sampler was programed to sample air continuously for $4 \mathrm{~h}$ during the day; later (May 5, 1995), this was changed to $5 \mathrm{~min}$ out of every hour to better represent average air concentrations. The GFF and the PUFs were replaced after 7 days. The GFFs were analyzed separately to provide an estimate of the phase distribution of the pesticides. The last air samples at both sites were collected for the week of September 12-19. At the agricultural site, equipment failures prevented the collection of samples for the weeks of July 5-12, July 25-August 1, and August 1-8.

The GFFs and PUFs were sent on ice to the NWQL where they were analyzed by a method based in part on the method used for the rain samples to facilitate data interpretation (Zaugg et al., 1995). This method is reported in Majewski et al. (this volume), and Foreman et al. (this volume).

\subsection{Quality assurance}

One rain field equipment blank (FEB) was collected at the Rolling Fork site in May 1995. Following routine field cleaning of the rain sampler, pesticide-free blank water was passed through the rain-collection equipment and then processed through the SPE method. Only propanil and metolachlor were detected in this FEB, at concentrations below the method reporting level. 
All rain samples were fortified before isolation on the SPE cartridge with surrogate compounds terbuthylazine, diazinon- $\mathrm{d}_{10}$, and $\alpha-\mathrm{HCH}-\mathrm{d}_{6}$ to monitor sample handling from this step through GC/MS analysis. Median recoveries for each sur- rogate were 122,121 , and $101 \%$, respectively. The minimum recovery was $75 \%$ for $\alpha-\mathrm{HCH}-\mathrm{d}_{6}$ and the maximum was $200 \%$ for diazinon- $\mathrm{d}_{10}$.

Storage losses of pesticides in collected rain was assessed using spiked rainwater from Iowa

Table 1

Pesticide detections in rain and air from agricultural and urban sites in Mississippi, April-September 1995 ${ }^{\mathrm{a}}$

\begin{tabular}{|c|c|c|c|c|c|c|}
\hline \multirow[t]{2}{*}{ Pesticide } & \multicolumn{2}{|c|}{ Urban detections } & \multicolumn{2}{|c|}{ Agricultural detections } & \multirow{2}{*}{$\begin{array}{l}\text { Rankings of } \\
\text { agricultural use }\end{array}$} & \multirow{2}{*}{$\begin{array}{l}\text { Urban use } \\
\text { in Mississippi } \\
(1990)^{\mathrm{c}}\end{array}$} \\
\hline & Rain & Air & Rain & Air & & \\
\hline Acetochlor (h) & $X^{d}$ & $\mathrm{ND}^{\mathrm{e}}$ & ND & ND & NR & NR \\
\hline Alachlor (h) & $\mathrm{X}$ & ND & $\mathrm{X}$ & ND & $20^{\mathrm{f}}$ & NR \\
\hline$\alpha-\mathrm{HCH}(\mathrm{i})$ & $\mathrm{X}$ & $X^{e}$ & ND & $\mathrm{X}$ & NA & NR \\
\hline Atrazine (h) & $\mathrm{X}$ & $\mathrm{X}$ & $\mathrm{X}$ & $X$ & 18 & Yes \\
\hline Benfluralin (h) & ND & $\mathrm{X}$ & ND & ND & NR & NR \\
\hline Butylate (h) & ND & ND & ND & $X^{d}$ & 75 & NR \\
\hline Carbaryl (i) & $\mathrm{X}$ & $\mathrm{X}$ & $\mathrm{X}$ & $X^{d}$ & 37 & Yes \\
\hline Carbofuran (i) & $\mathrm{X}$ & ND & $\mathrm{X}$ & $X^{d}$ & 38 & NR \\
\hline Chlorpyrifos (I) & $\mathrm{X}$ & $\mathrm{X}$ & $\mathrm{X}$ & $\mathrm{X}$ & 30 & Yes \\
\hline $\operatorname{CIAT}(\mathrm{m})^{\mathrm{g}}$ & $\mathrm{X}$ & $\mathrm{X}$ & $\mathrm{X}$ & $\mathrm{X}$ & NA & NA \\
\hline Cyanazine (h) & $\mathrm{X}$ & $\mathrm{X}$ & $\mathrm{X}$ & $\mathrm{X}$ & 9 & NR \\
\hline $\operatorname{DCPA}(\mathrm{h})$ & $\mathrm{X}$ & $X^{\mathrm{d}}$ & $\mathrm{X}$ & $\mathrm{X}$ & 94 & Yes \\
\hline$p, p^{\prime}-\mathrm{DDE}(\mathrm{m})$ & ND & $\mathrm{X}$ & ND & $\mathrm{X}$ & NA & NA \\
\hline Diazinon (i) & $\mathrm{X}$ & $\mathrm{X}$ & $\mathrm{X}$ & $\mathrm{X}$ & 92 & Yes \\
\hline Dieldrin (i) & $X^{d}$ & $X^{d}$ & $\mathrm{X}$ & $\mathrm{X}$ & Dc & Dc \\
\hline 2,6-Diethylaniline (m) & ND & ND & ND & $X$ & NA & NA \\
\hline Dimethoate (i) & $\mathrm{NA}^{\mathrm{h}}$ & $\mathrm{ND}^{\mathrm{e}}$ & NA & ND & 56 & Yes \\
\hline $\operatorname{CEAT}(m)^{\mathrm{i}}$ & $\mathrm{NA}^{\mathrm{h}}$ & $\mathrm{X}^{\mathrm{e}}$ & NA & $\mathrm{X}$ & NA & NA \\
\hline Disulfoton (I) & ND & $\mathrm{ND}^{\mathrm{j}}$ & ND & ND & 34 & Yes \\
\hline $\operatorname{EPTC}(\mathrm{h})$ & ND & $\mathrm{ND}^{\mathrm{j}}$ & $\mathrm{X}^{\mathrm{d}}$ & $\mathrm{X}$ & 65 & Yes \\
\hline Ethalfluralin (h) & ND & $\mathrm{ND}^{\mathrm{j}}$ & ND & ND & 49 & NR \\
\hline Ethoprop (i) & ND & ND & $X^{\mathrm{d}}$ & $\mathrm{X}$ & 96 & NR \\
\hline Fonofos (i) & ND & ND & ND & ND & NR & NR \\
\hline Lindane (i) & ND & $\mathrm{X}^{\mathrm{d}}$ & ND & $\mathrm{X}$ & 102 & NR \\
\hline Linuron (h) & ND & ND & $X^{\mathrm{d}}$ & ND & 44 & NR \\
\hline Malathion (I) & $\mathrm{X}$ & $\mathrm{X}^{\mathrm{j}}$ & $\mathrm{X}$ & $\mathrm{X}$ & 21 & Yes \\
\hline Methyl azinphos (i) & $\mathrm{X}$ & $\mathrm{ND}^{\mathrm{e}}$ & $\mathrm{X}$ & $\mathrm{X}$ & 47 & Yes \\
\hline Methyl parathion (i) & $\mathrm{X}$ & $\mathrm{X}$ & $\mathrm{X}$ & $\mathrm{X}$ & 1 & NR \\
\hline Metolachlor (h) & $\mathrm{X}$ & $\mathrm{X}^{\mathrm{j}}$ & $\mathrm{X}$ & $\mathrm{X}$ & 12 & NR \\
\hline Metribuzin (h) & ND & ND & ND & $\mathrm{X}$ & 27 & NR \\
\hline Molinate (h) & $\mathrm{X}$ & $X^{d}$ & $\mathrm{X}$ & $\mathrm{X}$ & 23 & NR \\
\hline Napropamide (h) & ND & ND & ND & ND & 101 & NR \\
\hline Parathion (i) & ND & ND & $X^{\mathrm{d}}$ & ND & NR & NR \\
\hline Pebulate (h) & $X^{\mathrm{d}}$ & $\mathrm{ND}^{\mathrm{j}}$ & ND & ND & NR & NR \\
\hline Pendimethalin (h) & $X^{d}$ & ND & $X$ & $\mathrm{X}$ & 13 & Yes \\
\hline cis-Permethrin (i) & $X^{d}$ & $\mathrm{X}$ & ND & ND & 77 & Yes \\
\hline Phorate (i) & ND & ND & ND & ND & 62 & NR \\
\hline Prometon (h) & $\mathrm{X}$ & $\mathrm{NA}^{\mathrm{k}}$ & $X$ & NA & NR & Yes \\
\hline Pronamide (h) & ND & ND & ND & ND & NR & NR \\
\hline Propachlor (h) & ND & ND & ND & ND & NR & NR \\
\hline Propanil (h) & $\mathrm{X}$ & $X$ & $\mathrm{X}$ & $\mathrm{X}$ & 6 & NR \\
\hline Propargite I \& II (i) & ND & $\mathrm{ND}^{\mathrm{j}}$ & ND & ND & NR & NR \\
\hline Simazine (h) & $X^{d}$ & $\mathrm{X}$ & $\mathrm{X}$ & ND & 87 & Yes \\
\hline
\end{tabular}


Table 1 (Continued)

\begin{tabular}{|c|c|c|c|c|c|c|}
\hline \multirow[t]{2}{*}{ Pesticide } & \multicolumn{2}{|c|}{ Urban detections } & \multicolumn{2}{|c|}{ Agricultural detections } & \multirow{2}{*}{$\begin{array}{l}\text { Rankings of } \\
\text { agricultural use }\end{array}$} & \multirow{2}{*}{$\begin{array}{l}\text { Urban use } \\
\text { in Mississippi }{ }^{\mathrm{b}}{ }^{\mathrm{c}} \\
(1990)^{\mathrm{c}}\end{array}$} \\
\hline & Rain & Air & Rain & Air & & \\
\hline Tebuthiuron (h) & ND & $\mathrm{NA}^{\mathrm{k}}$ & ND & NA & NR & NR \\
\hline Terbacil (h) & ND & $\mathrm{ND}^{\mathrm{j}}$ & $X^{\mathrm{d}}$ & ND & NR & NR \\
\hline Terbufos (i) & ND & ND & ND & ND & 54 & NR \\
\hline Thiobencarb (h) & $\mathrm{X}$ & ND & $\mathrm{X}$ & $\mathrm{X}$ & 31 & NR \\
\hline Triallate $(\mathrm{h})$ & ND & $\mathrm{ND}^{\mathrm{e}}$ & ND & ND & NR & NR \\
\hline Trifluralin (h) & $\mathrm{X}$ & $\mathrm{X}$ & $\mathrm{X}$ & $\mathrm{X}$ & 3 & Yes \\
\hline
\end{tabular}

${ }^{\mathrm{a}}$ Abbreviations: h, herbicide; X, detected; ND, not detected; m, metabolite; NR, not reported; i, insecticide; NA, not applicable; dc, discontinued; unk, unknown).

${ }^{\mathrm{b}}$ From Majewski and Capel (1995).

${ }^{\mathrm{c}}$ From Gianessi and Puffer (1991, 1992a,b).

${ }^{\mathrm{d}}$ Detected once.

${ }^{\mathrm{e}}$ Method performance data are not available.

${ }^{\mathrm{f}} \mathrm{Gaps}$ in rankings due to pesticides not included in this study.

${ }^{\mathrm{g}}$ CIAT, chloroisopropylaminotriazine.

${ }^{\mathrm{h}}$ Analyzed for in air only.

${ }^{\mathrm{i}}$ CEAT, chloroethylaminotriazine.

${ }^{\mathrm{j}}$ Recovery of spiked sample was less than $60 \%$ from Majewski et al. (1998).

${ }^{\mathrm{k}}$ Analyzed for in rain only.

City, Iowa, another sample location included in this study (Majewski, et al., this volume). Spiked rainwater was held for 5 days at room temperature and no apparent losses were observed for most pesticides, since beginning and end recoveries were in the range of expected recoveries for the SPE method (Zaugg et al., 1995). Compounds showing the greatest losses $(20-45 \%)$ on storage were benfluralin, ethalfluralin, trifluralin, butylate, diazinon, and terbufos. Less loss would be expected under the refrigerated storage conditions used for field rain samples. Goolsby et al. (1997) observed no appreciable loss of selected triazine and chloroacetanilide herbicides in spiked rainwater stored in plastic rain sampling buckets under ambient temperature field conditions.

Pesticide collection efficiencies for the PUF plugs were evaluated using the collection experiment described in Majewski et al. (1998) and Foreman et al. (this volume). Collection efficiencies for most compounds at the $850-\mathrm{m}^{3}$ air volumes typical for this study were excellent, except for those compounds noted in Table 1. Five PUF laboratory blanks were processed during the study, and only one compound (CEAT) was detected in one sample. Four air FEB samples were collected throughout the study (one from Jackson and three from Rolling Fork). Each consisted of two PUFs and one GFF briefly placed in the sampler and then removed. Substantial amounts of some pesticides were found (0.03-153 ng). However, when adjusted for typical sample volumes, the maximum concentrations of any compound detected in these blanks was 0.18 $\mathrm{ng} / \mathrm{m}^{3}$ (tebuthiuron). Mean laboratory spike recoveries ranged from $37 \pm 28 \%$ for tebuthiuron (which exhibited losses during the Florisil clean-up step) to $140 \pm 56 \%$ for carbaryl, with an overall mean recovery of $92 \pm 20 \%$ for all compounds (Foreman et al. this volume). Estimates of method reporting levels were provided by Majewski et al. (1998), and ranged from approximately 0.006 $\mathrm{ng} / \mathrm{m}^{3}$ for atrazine to $0.1 \mathrm{ng} / \mathrm{m}^{3}$ for prometon for an $850-\mathrm{m}^{3}$ air volume. Estimated concentrations below the reporting levels were used if all GC/MS-SIM qualifying information were obtained (Zaugg et al., 1995). Further information on the air method and quality assurance data can be found in Forman et al. (this volume).

\section{Results}

The pesticides for which the rain and air samples were analyzed are listed in Table 1. The agricultural pesticide-use rankings for Mississippi 
are also listed along with possible urban use. Descriptive statistics for occurrence and concentrations of several of the frequently detected pesticides are listed in Table 2.

\subsection{Pesticides in rain}

Twenty-five of 47 measured pesticides were de- tected at least once in rain samples from the urban site (Table 1). Methyl parathion was measured in the highest concentration. Methyl parathion is an insecticide that is used very heavily on row crops in Mississippi, but it is not registered for use in urban areas. Five pesticides (four insecticides and one herbicide) were measured in more than $50 \%$ of the rain samples from

Table 2

Statistics on selected pesticides in rain and air $^{\mathrm{a}}$

\begin{tabular}{|c|c|c|c|c|c|c|c|c|c|}
\hline \multirow[t]{2}{*}{ Pesticide } & \multirow{2}{*}{$\begin{array}{l}\text { Phase rain }(\mu \mathrm{g} / \mathrm{l}) \\
\text { gas and particulate } \\
\left(\mathrm{ng} / \mathrm{m}^{3}\right)\end{array}$} & \multicolumn{4}{|c|}{ Urban } & \multicolumn{4}{|c|}{ Agriculture } \\
\hline & & $\#$ & Max & Med & $\%$ & $\#$ & Max & Med & $\%$ \\
\hline \multirow[t]{3}{*}{ Atrazine } & Rain & 16 & 0.096 & 0.006 & 69 & 16 & 0.83 & 0.02 & 75 \\
\hline & Gas & 24 & nd & nd & 0 & 21 & 2.6 & nd & 42 \\
\hline & Particulate & 24 & 0.019 & nd & 29 & 21 & 0.42 & 0.058 & 67 \\
\hline \multirow[t]{3}{*}{ Chlorpyrifos } & Rain & 16 & 0.009 & 0.005 & 63 & 16 & 0.04 & $<0.005$ & 38 \\
\hline & Gas & 24 & 3.5 & 1.5 & 96 & 21 & 3.1 & nd & 38 \\
\hline & Particulate & 24 & nd & nd & 0 & 21 & nd & nd & 0 \\
\hline \multirow[t]{3}{*}{ Cyanazine } & Rain & 16 & 0.074 & $<0.013$ & 31 & 16 & 0.32 & 0.008 & 56 \\
\hline & Gas & 24 & 0.61 & nd & 8 & 21 & 0.25 & nd & 5 \\
\hline & Particulate & 24 & nd & nd & 0 & 21 & 0.39 & nd & 24 \\
\hline \multirow[t]{3}{*}{ Diazinon } & Rain & 16 & 0.019 & 0.005 & 56 & 16 & 0.013 & $<0.008$ & 13 \\
\hline & Gas & 24 & 8.4 & 0.14 & 50 & 21 & 1.4 & nd & 10 \\
\hline & Particulate & 24 & 0.2 & nd & 25 & 21 & nd & nd & 0 \\
\hline \multirow[t]{3}{*}{ Methyl parathion } & Rain & 16 & 0.3 & 0.024 & 56 & 16 & 22.9 & 0.12 & 69 \\
\hline & Gas & 24 & 0.99 & nd & 46 & 21 & 62 & 2.5 & 71 \\
\hline & Particulate & 24 & nd & nd & 0 & 21 & 0.4 & nd & 29 \\
\hline \multirow[t]{3}{*}{ Molinate } & Rain & 16 & 0.025 & $<0.004$ & 25 & 16 & 0.37 & 0.026 & 67 \\
\hline & Gas & 24 & 0.44 & nd & 4 & 21 & 3.4 & 0.076 & 62 \\
\hline & Particulate & 24 & nd & nd & 0 & 21 & 0.089 & nd & 5 \\
\hline \multirow[t]{3}{*}{ Propanil } & Rain & 16 & 0.14 & $<0.016$ & 38 & 16 & 1.8 & 0.036 & 81 \\
\hline & Gas & 24 & 0.24 & nd & 13 & 21 & 7.6 & 0.37 & 57 \\
\hline & Particulate & 24 & 0.043 & nd & 21 & 21 & 4.3 & 0.54 & 62 \\
\hline \multirow[t]{3}{*}{$p, p^{\prime}-\mathrm{DDE}$} & Rain & 16 & $<0.006$ & $<0.006$ & 0 & 16 & $<0.006$ & $<0.006$ & 0 \\
\hline & Gas & 24 & 0.19 & nd & 33 & 21 & 1.1 & 0.67 & 100 \\
\hline & Particulate & 24 & nd & nd & 0 & 21 & 0.019 & 0.01 & 52 \\
\hline \multirow[t]{3}{*}{ Trifluralin } & Rain & 16 & 0.01 & $<0.002$ & 13 & 16 & 0.024 & 0.007 & 69 \\
\hline & Gas & 24 & 0.76 & 0.028 & 88 & 21 & 5.5 & 0.81 & 100 \\
\hline & Particulate & 24 & nd & nd & 0 & 21 & 0.013 & nd & 5 \\
\hline
\end{tabular}

${ }^{\mathrm{a}}$ Abbreviations: $\mu \mathrm{g} / \mathrm{l}$, micrograms per liter; $\mathrm{ng} / \mathrm{m}^{3}$, nanograms per cubic meter; \#, number of samples; $\%$, percent of sample detections; max, maximum concentrations; med, median concentration; nd, not determined. 
the urban site: carbaryl, chlorpyrifos, diazinon, methyl parathion, and atrazine. No pesticide concentration exceeded $0.5 \mu \mathrm{g} / \mathrm{l}$.

Twenty-six of 47 measured pesticides were detected at least once in rain from the agricultural site (Table 1). The pesticide measured in the highest concentration was methyl parathion. Eight pesticides (one insecticide and seven herbicides) were detected in more than $50 \%$ of the rain samples from the agricultural site; methyl parathion, atrazine, cyanazine, metolachlor, molinate, pendimethalin, propanil, and trifluralin. There were three pesticides measured at concentrations higher than $0.5 \mu \mathrm{g} / \mathrm{l}$; they were atrazine $(0.83 \mu \mathrm{g} / \mathrm{l})$, methyl parathion (8.6 and $22.9 \mu \mathrm{g} / \mathrm{l})$, and propanil $(1.8 \mu \mathrm{g} / \mathrm{l})$.

\subsection{Pesticides in air}

Twenty-one of 47 measured pesticides were detected in air (GFF and PUFs) from the urban site (Table 1). The most frequently detected pesticide was chlorpyrifos, followed by trifluralin and diazinon. Four pesticides (three insecticides and one herbicide) were detected in more than $50 \%$ of the samples; chlorpyrifos, diazinon, cis-permethrin, and trifluralin. Methyl parathion was measured in 11 of the 24 samples.

Twenty-seven of 47 pesticides were detected in air from the agricultural site (Table 1). The most frequently detected pesticides were trifluralin and $p, p^{\prime}$-DDE, a metabolite of DDT; they were detected in every sample. Four other pesticides were also detected in more than $50 \%$ of the air samples: atrazine, methyl parathion, molinate, and propanil.

\section{Discussion}

Previous studies of pesticides in the atmosphere have indicated that the highest concentrations typically are seasonal and correspond to local use, usually originating within tens of kilometers of the collection point, and that there is a component related to long-range transport, usually only identifiable before or after use and the planting season (Majewski and Capel, 1995). Be- cause sampling occurred during the growing season, the concentrations reported here are probably related to local use. This would indicate that a component of the pesticides in the air at the urban site would be from agriculture, as there is intensive agriculture within a $100-\mathrm{km}$ radius of Jackson, Mississippi.

Pesticide use for agricultural purposes is well documented; however, urban pesticide use, which includes consumer applications in and around the home and professional application in industrial settings, golf courses, parks, cemeteries, roadways, and railroads, is not well documented. Therefore, comparisons of the occurrence of pesticides in the atmosphere as the occurrence relates to local use, while practical for the agricultural sites, is more difficult for an urban setting. In general, the distribution of the detected pesticides in rain and air, within the urban and agricultural data in this study is quite different. The concentrations of pesticides in rain and air, in general, are higher at the agricultural site than at the urban site, and the types of pesticides detected reflect their local use, although in the case of the urban site there were some agricultural pesticides detected. In urban rain and air, the insecticides carbaryl, chlorpyrifos, and diazinon were detected more frequently than at the agricultural sites. These insecticides are used heavily in the south for fire ant and termite control; their use in agricultural settings is limited. [Note: Although chlorpyrifos is used heavily in agricultural settings in other States, its use in Mississippi has been limited since 1993, because of concerns about residues detected in farm-raised catfish ( $R$. McCarty, Bur. of Plant Industry, written communication, 1997)].

\subsection{Pesticides in rain}

The total pesticide concentrations in rain for samples collected at the urban and agricultural site are shown in Fig. 2. The stacked bars show concentrations in $\mu \mathrm{g} / \mathrm{l}$ for atrazine, carbaryl, methyl parathion, propanil, and other. The other category is an aggregation of those pesticides infrequently detected. The total pesticide concentrations were 5-10 times higher at the agricul- 


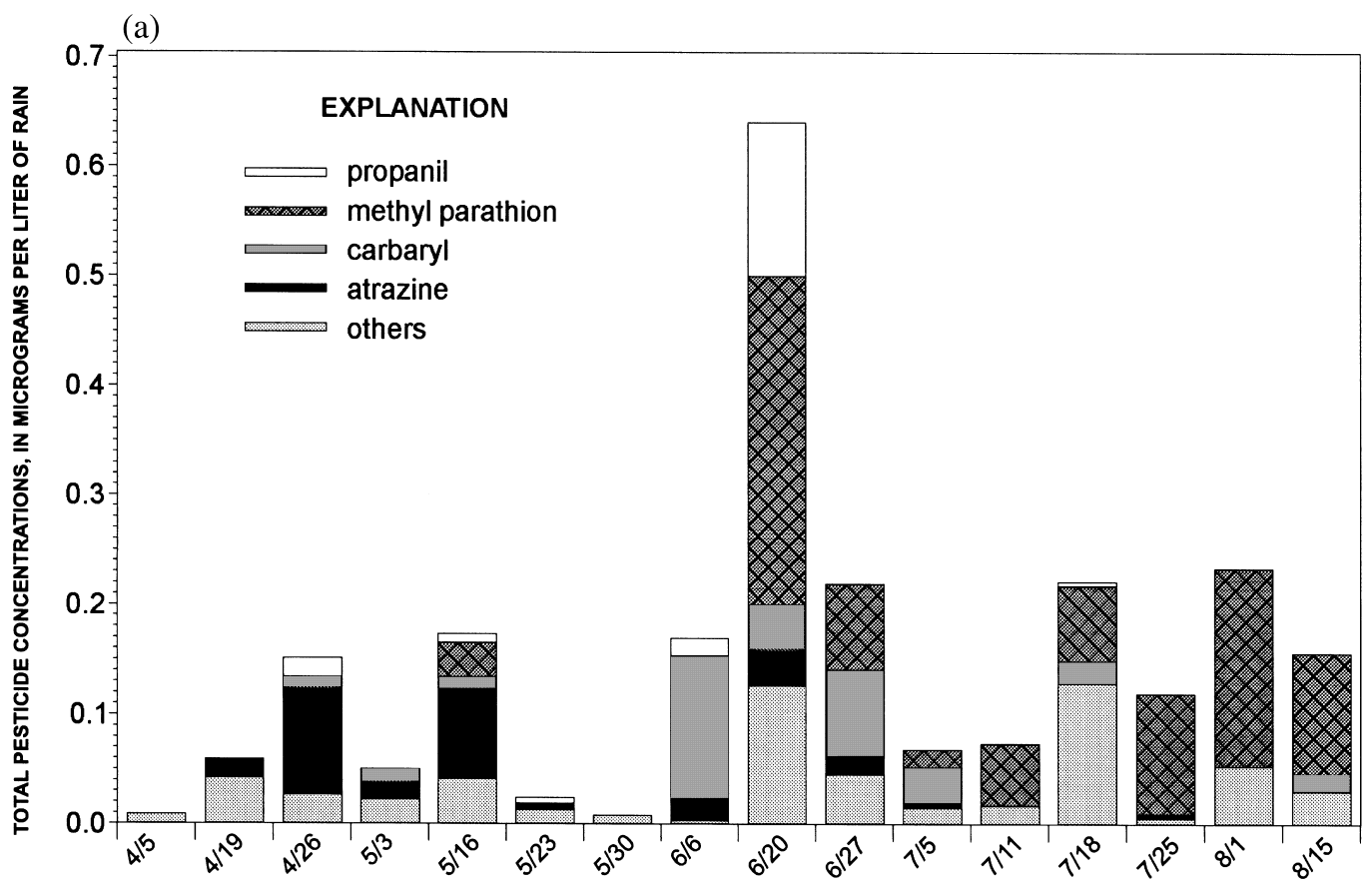

(b)

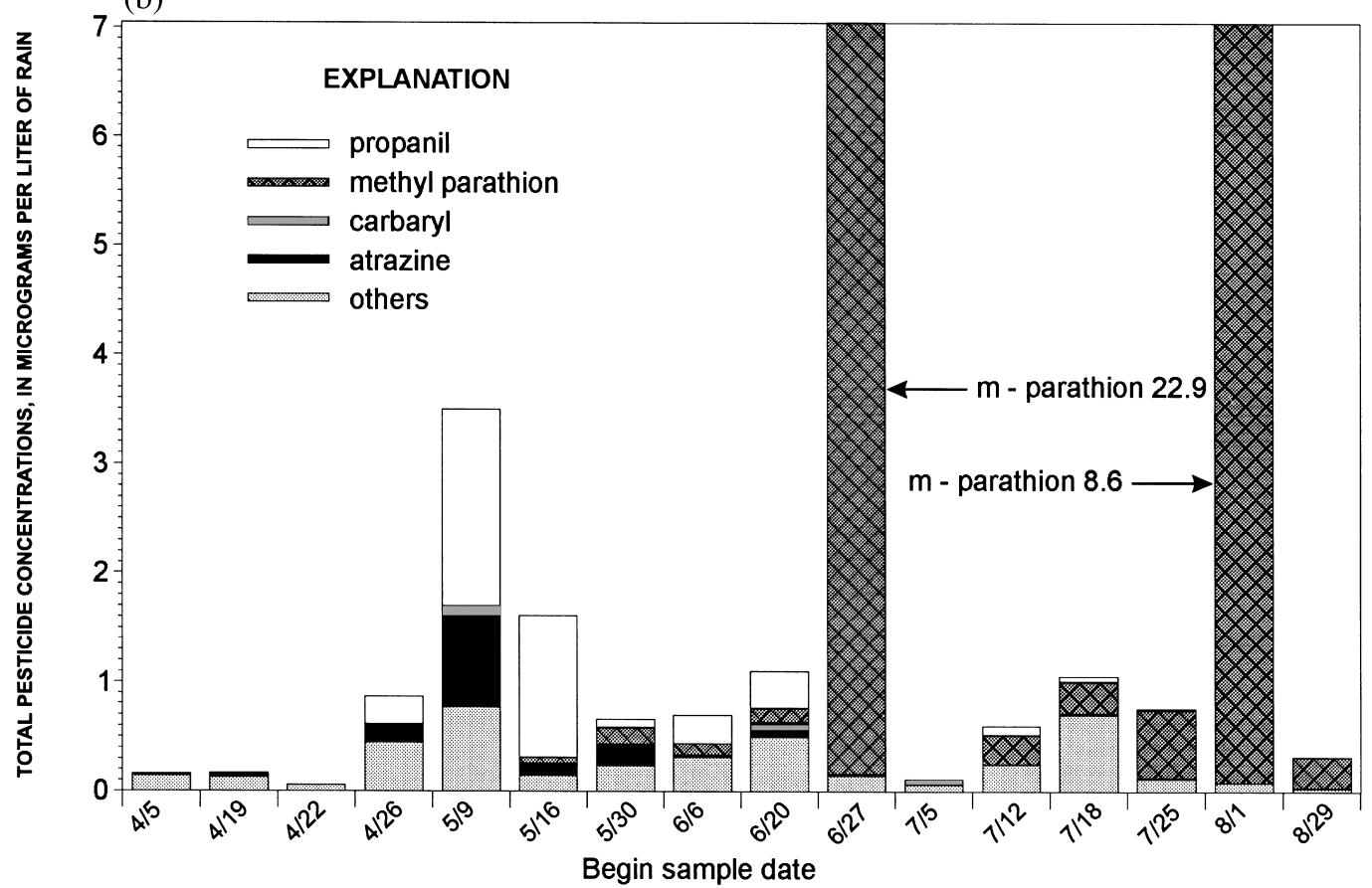

Fig. 2. Pesticide concentrations in rain samples collected from an (a) urban and (b) agricultural site in Mississippi, April-September, 1995. 
tural site, reflecting the heavy use of agricultural chemicals on local crops. The pesticides making up a large proportion of the total concentrations in rain at the urban site were atrazine, carbaryl, methyl parathion, and propanil. Because methyl parathion and propanil do not have any legal urban uses, it is assumed that these pesticides were transported from agricultural areas. Methyl parathion and propanil, respectively, are the first and sixth heaviest used pesticides in Mississippi. Atrazine, methyl parathion, and propanil, with some metolachlor and molinate dominate the total pesticide concentrations in rain at the agricultural site. In two rain samples (weeks beginning June 27 and August 1), the concentrations of methyl parathion, 22.9 and $8.6 \mu \mathrm{g} / \mathrm{l}$, were very high compared to the concentrations of other pesticides in rain. The highest concentrations of methyl parathion in air, 55.6 and $62.5 \mathrm{ng} / \mathrm{m}^{3}$ occurred during the weeks of August 8 and $\mathrm{Au}-$ gust 15 , respectively, corresponding to weeks with little or no rain. The week of the highest concentration in rain (June 27, $22.9 \mu \mathrm{g} / \mathrm{l}$ ), the concentration in the air sample was $10.8 \mathrm{ng} / \mathrm{m}^{3}$. The data in Table 2 indicate that methyl parathion is present in rain and air. Methyl parathion must be easily scavenged from the air by raindrops but will persist in the atmosphere without rain and, therefore, is available to be transported from the point of application. This is consistent with the presence of methyl parathion at the urban site.

In a paired study that looked at the differences in triazine concentrations (atrazine, cyanazine, simazine, terbutylazine) between a rural site and an urban site, Chevreuil (1996) noted that there was no difference in diversity and abundances of these herbicides in bulk deposition (rain and particulate phases) between the two sites. This was attributed to the fact that the urban site, located in Paris, France, is relatively small and surrounded by an area of intense agriculture. The concentrations in the French study were similar to those found at the urban and rural sites in Mississippi. From Fig. 2 and Table 2, it appears that there is a difference in concentrations of atrazine and cyanazine between the urban and agricultural site, although there are too few data above the reporting level to determine if this is a statistically significant difference. However, when examining the total pesticide concentrations in rain, it is clear that there is a difference between the urban and agricultural sites. Nations and Hallberg (1992) noted a difference in pesticide concentrations between an urban and a rural site in Iowa. The herbicides were detected as frequently at both sites, but the rural site had higher concentrations than the urban site. The urban site had most of the insecticide detections (fonofos, malathion, and methyl parathion); this was related to urban lawn and garden use. The concentrations of the corn and soybean herbicides in the Iowa study were higher than those measured at the agricultural site in Mississippi.

Nations and Hallberg (1992) and Chevreuil et al. (1996) noted an annual cycle for the triazines: a rapid rise of the concentrations corresponding with spring planting and a decrease to a minimum by the end of summer. Although a similar cycle was noted in this study in Mississippi for the triazine herbicides, the total concentration of pesticides does not appear to follow this cycle as closely. There are multiple pesticide concentration peaks corresponding to varying planting dates for different crops, followed by post-emergent herbicide applications and applications of insecticides for pest control.

\subsection{Pesticides in air}

The pesticide concentrations in air at the urban and agricultural sites are shown in Fig. 3. The stacked bars show air concentrations in $\mathrm{ng} / \mathrm{m}^{3}$ for carbaryl, chlorpyrifos, diazinon, methyl parathion, pendimethalin, trifluralin, and other. The other category is an aggregation of pesticides infrequently detected. The other category for the air samples at the agricultural sites collected during the weeks of May 3, May 10, and May 16 was dominated by thiobencarb and propanil. Total pesticide concentrations in air (GFF and PUFs combined) were higher at the agricultural site, and the makeup of the total concentrations was different. Total pesticide concentration in air at the urban site was dominated by chlorpyrifos and diazinon, with smaller amounts of carbaryl, methyl parathion, and trifluralin. At the agricultural site, 
the total pesticide concentration in air was dominated by a number of different pesticides at dif- ferent times. At the start of the study, in April, the herbicides pendimethalin and trifluralin made
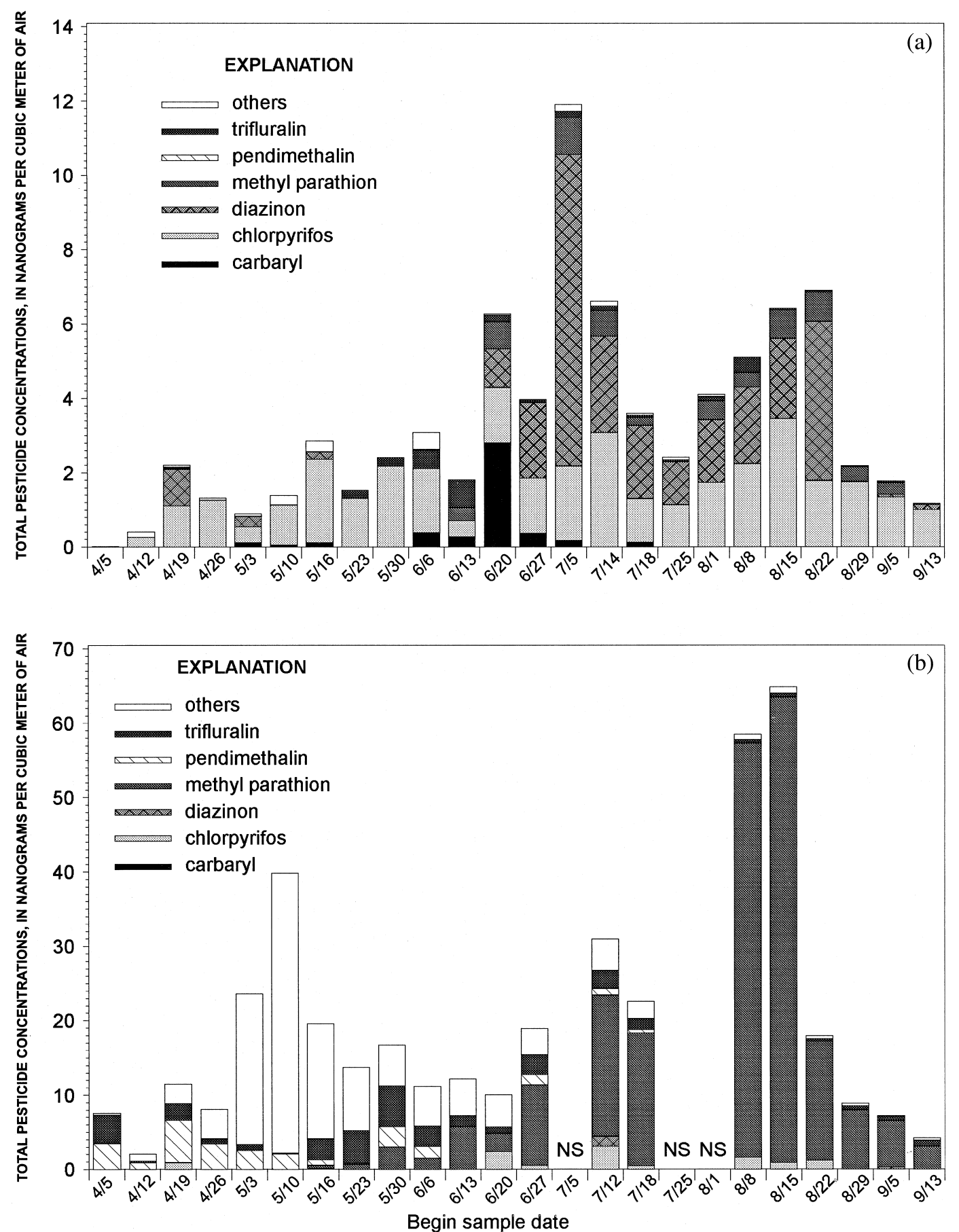

Fig. 3. Pesticide concentrations in air samples collected from an (a) urban and (b) agricultural site in Mississippi, April-September, 1995 (NS, no sample). 
up the majority of the total concentrations. At the beginning of May, the two major pesticides were the rice herbicides propanil and thiobencarb. Towards the end of the study, the insecticide methyl parathion was the dominant pesticide. The occurrence of these pesticides in the air was related to local application times on cotton and rice.

In two studies conducted in the late 1960s and early 1970s air was sampled for methyl parathion near Stoneville, Mississippi, approximately $70-\mathrm{km}$ north of Rolling Fork. Stanley et al. (1971) collected 24-h samples during 1967 and 1968. Most of the samples were collected during July through to October, the high use period for methyl parathion. The concentrations of methyl parathion in air for the months of August and September ranged from 20.6 to $71.0 \mathrm{ng} / \mathrm{m}^{3}$. The results for this study compare well with Stanley's data collected approximately three decades ago. Arthur et al. (1976) presented average monthly concentrations of methyl parathion for 1972-1974. The average monthly concentrations of methyl parathion for August of 1972-1974 were 217, 129, and $341 \mathrm{ng} / \mathrm{m}^{3}$ for the 3 years, respectively. The concentrations of methyl parathion in air from Arthur's study are higher than those presented in this study. The authors for Arthur's study noted some anomalous results in that the concentrations of methyl parathion in air in 1973 was much higher than in 1972 overall, although there had been a $38 \%$ reduction in its use from 1972 to 1973.

Stanley et al. (1971) detected $p, p^{\prime}$-DDE in concentrations ranging from 2.6 to $7.1 \mathrm{ng} / \mathrm{m}^{3}$ during April through to September 1967. The range of $p, p^{\prime}$-DDE concentrations at the agricultural site in this study was from 0.13 to $1.1 \mathrm{ng} / \mathrm{m}^{3}$, lower than Stanley's, but still significant considering that DDT was banned in the United States in 1972. These results indicate that a persistent $p, p^{\prime}$-DDT degradation product was still measurable in the air more than two decades after DDT use was banned in the United States.

\subsection{Factors affecting the occurrence of pesticides in rain}

There are numerous mechanisms that can de-
Table 3

Water solubility, vapor pressure, and Henry's law constant (between 20 and $25^{\circ} \mathrm{C}$ ) for selected compounds ${ }^{\mathrm{a}}$

\begin{tabular}{|c|c|c|c|}
\hline \multirow[t]{2}{*}{ Compound } & \multicolumn{2}{|c|}{ Subcooled liquid $^{\mathrm{b}}$} & \multirow{2}{*}{$\begin{array}{l}\text { Henry's law } \\
\text { constant } \\
\left(\mathrm{Pa} \mathrm{m}^{3} / \mathrm{mol}\right)\end{array}$} \\
\hline & $\begin{array}{l}\text { Water } \\
\text { solubility } \\
\left(\mathrm{mol} / \mathrm{m}^{3}\right)\end{array}$ & $\begin{array}{l}\text { Vapor } \\
\text { pressure } \\
(\mathrm{Pa})\end{array}$ & \\
\hline Atrazine & $4.48 \mathrm{E}+00$ & $1.29 \mathrm{E}-03$ & $2.87 \mathrm{E}-04$ \\
\hline Chlorpyrifos & $1.25 \mathrm{E}-03$ & 2.19E-03 & $1.75 \mathrm{E}+00$ \\
\hline Cyanazine & $1.85 \mathrm{E}+01$ & $5.21 \mathrm{E}-06$ & $2.82 \mathrm{E}-07$ \\
\hline Diazinon & $1.25 \mathrm{E}-01$ & $8.00 \mathrm{E}-03$ & $6.41 \mathrm{E}-02$ \\
\hline Methyl parathion & $1.27 \mathrm{E}-01$ & $2.67 \mathrm{E}-03$ & $2.11 \mathrm{E}-02$ \\
\hline Molinate & $4.70 \mathrm{E}+00$ & 7.46E-01 & $1.59 \mathrm{E}-01$ \\
\hline Propanil & $6.50 \mathrm{E}+00$ & $2.36 \mathrm{E}-02$ & $3.64 \mathrm{E}-03$ \\
\hline$p, p^{\prime}-\mathrm{DDE}$ & $5.48 \mathrm{E}-04$ & $4.36 \mathrm{E}-03$ & $7.95 \mathrm{E}+00$ \\
\hline Trifluralin & $2.44 \mathrm{E}-03$ & $9.84 \mathrm{E}-03$ & $4.03 E+00$ \\
\hline
\end{tabular}

liver organic compounds to the atmosphere, such as volatilization, wind erosion of soil particles to which pesticides are attached, and direct spraying of the compound to the atmosphere during pesticide application. Once in the atmosphere, a compound will distribute among the aqueous, gaseous, and particulate phases based on the physical and chemical properties of the compound, including water solubility and vapor pressure, and on the conditions of the atmosphere such as temperature, moisture content, and the type and concentration of particulate matter. The phase distribution of the compound strongly affects the behavior, transport, and ultimate fate of the compound in the atmosphere. The water solubility, vapor pressure, and Henry's law constant for selected compounds that were frequently detected at either the urban or agricultural site or both are listed in Table 3.

Chlorpyrifos, $p, p^{\prime}$-DDE, diazinon, methyl parathion, molinate, and trifluralin were detected largely or exclusively on the PUF and rarely on the GFF and, thus, were primarily in the gaseous phase in air. Wet deposition of these pesticides should be dominated by gas scavenging and related to the Henry's law constant for the pesticide. Of these pesticides, chlorpyrifos, $p, p^{\prime}$-DDE, and trifluralin have relatively lower water solubili- 
ties and higher Henry's constants. Consequently, less (gaseous) pesticide mass should be scavenged, resulting in less frequent detections in rain relative to other pesticides having comparable air concentrations and detection levels in rain but lower Henry's constants. This appears to be the case for $p, p^{\prime}$-DDE. However, the frequency of detection in rain for chlorpyrifos at both the urban and agricultural sites and for trifluralin at the agricultural site, compared with the frequency of detection in air, was not different from the frequency of detection in rain of diazinon, molinate, and methyl parathion, pesticides with lower Henry's constants and higher water solubilities.

Reduced air concentrations are partly caused by dilution effects as air parcels are transported away from pesticide application sites. Furthermore, pesticides such as trifluralin and molinate are susceptible to photochemical degradation reactions (Grover, 1991), the rates for which can be stimulated by increased concentrations of oxidants, such as ozone, that typically are present in higher concentrations in urban vs. rural atmospheres (Finlayson-Pitts and Pitts, 1986). Trifluralin and molinate concentrations in air at the urban site were approximately 1 order of magnitude lower than at the agricultural site. These lower concentrations in air resulted in reduced frequencies of detectable rain concentrations relative to the agricultural site.

Atrazine and propanil were detected in substantial concentrations in both the gaseous and particulate phases in air at the agricultural site. These pesticides have relatively high water solubilities and low Henry's constants. Therefore, scavenging of these pesticides by rain from both sources is important. Detection of these pesticides in rain was more frequent than in air at both sites.

\section{Conclusions}

Every rain and air sample collected from an urban and an agricultural site in Mississippi during April-September 1995 had detectable levels of multiple pesticides. The magnitude of the total concentration was five to 10 times higher at the agricultural site as compared to the urban site. The pesticide with the highest concentrations in rain at both sites was methyl parathion. Methyl parathion was also the pesticide in the highest concentration in air from the agricultural site, but at the urban site, the pesticide in the highest concentration in air was diazinon followed closely by chlorpyrifos. More than two decades since $p, p^{\prime}$-DDT was banned from use in the United States, $p, p^{\prime}$-DDE, a metabolite of $p, p^{\prime}$-DDT, was detected in every air sample collected from the agricultural site and in more than half of the air samples from the urban site. The occurrence of pesticides in rain and air at the agricultural site was related to the timing of application and local use. The occurrence of pesticides in urban rain and air for which there are no legal uses in an urban area was related to transport through the atmosphere from areas of heavy agricultural use.

\section{References}

Arthur RD, Cain JD, Barrentine BF. Atmospheric levels of pesticides in the Mississippi Delta. Bull Environ Contam Toxicol 1976;15(2):129-134.

Chevreuil M, Gramouma M, Teil MJ, Chesterifkoff A. Occurrence of organochlorines (PCBs, pesticides) and herbicides (triazine, phenylureas) in the atmosphere and in the fallout from urban and rural stations of the Paris area. Sci Total Environ 1996;182:25-37.

Finlayson-Pitts BJ, Pitts JN. Atmospheric chemistry: fundamental and experimental techniques. New York: John Wiley and Sons, 1986:638.

Gianessi LP, Puffer CA. Herbicide use in the United States: Washington, DC. Resources for the future, 1990 (1991):128.

Gianessi LP, Puffer CA. Fungicide use in the United States: Washington, DC. Resources for the future, 1992.

Gianessi LP, Puffer CA. Insecticide use in the United States: Washington, DC. Resources for the future, 1992.

Goolsby DA, Thurman EM, Pomes ML, Meyer MT, Battaglin WA. Herbicides and their metabolites in rainfall: origin, transport, and deposition patterns across the midwestern and northeastern United States, 1990-1991. Environ Sci Technol 1997;31(5):1325-1333.

Grover R. Nature, transport, and fate of airborne residues. In: Grover R, Cessna AJ, editors. Environmental chemistry of herbicides, II. Boca Raton, Fl: CRC Press, 1991:89-117.

Harper LA, McDowell LL, Willis GH, Smith S, Southwick LM. Microclimate effects on toxaphene and DDT volatilization from cotton plants. Agron J 1983;75:295-301.

Hollingsworth EB. Volatility of trifluralin from field soil. J Weed Sci 1980;28(2):224-228.

Kutz FW, Yobs AR, Yang SC. National pesticide monitoring 
programs. Air pollution from pesticides and agricultural processes. Cleveland Ohio: CRC Press, 1976:95-136.

Majewski MS, Capel PD. Pesticides in the atmosphere. Chelsea, Michigan: Ann Arbor Press, 1995:214.

Majewski MS, Foreman WT, Goolsby DA, Nakagaki N. Airborne pesticide residues along the Mississippi River. Environ Sci Technol 1998;32(23):3689-3698.

Nations BK, Hallberg GR. Pesticides in Iowa precipitation. J Environ Qual 1992;21:486-492.

Stanley CW, Barney II JE, Helton MR, Yobs AR. Measurement of atmospheric levels of pesticides. Environ Sci Technol 1971;5(5):430-435.

Tabor EC. Pesticides in urban atmospheres. J Air Poll Cont 1965;15(9):415-418.
Willis GH, McDowell LL, Smith S, Southwick LM, Lemon ER. Toxaphene volatilization from a mature cotton crop canopy. Agron J 1980;72:627-631.

Willis GH, McDowell LL, Harper LA, Southwick LM, Smith S. Seasonal disappearance and volatilization of toxaphene and DDT from a cotton field. J Environ Qual 1983; 12(1):80-85.

Zaugg SD, Sandstrom MW, Smith SG, Fehlberg KM. Methods of analysis by the US Geological Survey National Water Quality Laboratory - determination of pesticides in water by $\mathrm{C}-18$ solid-phase extraction and capillary-column gas chromatography/mass spectrometry with selected-ion monitoring. US Geological Survey Open-File Report 95-181, 1995:49. 